\title{
The antimicrobial and bactericidal activity of secondary amine with 2-hydroxyethyl group
}

\begin{abstract}
Recently we reported on the possibility of selective alkylation of monoethanolamine (MEA) in phase transfer catalysis (PTC) conditions. ${ }^{1}$ The direct mono-N alkylation of MEA with alkyl bromides as electrophilic reagent was performed in PTC system. This report is devoted to the study of the antimicrobial activity of the compounds obtained.
\end{abstract}

Keywords: monoethanolamine, phase transfer catalysis, alkyl derivatives of MEA, antimicrobial activity, Staph aureus, E. coli 0 III B:4. the bactericidal properties

\author{
Volume 2 Issue 3 - 2018
}

Torosyan GH, Hovhannisyan NR

Environmental Engineering Department, National polytechnic university of Armenia, Armenia

Correspondence: Torosyan GH, National polytechnic university of Armenia, Armenia, Yerevan Gagik Torosyan, Doctor of Chemical sciences, professor, National polytechnic university of Armenia, Armenia, Tel 374I-5546 48,

Email gagiktorosyan@seua.am

Received: May 22, 2018 | Published: June 07, 2018

\section{Opinion}

Alkyl derivatives of MEA are used in the production of surfactants, dyes, in the manufacture of drugs as a buffer substance and for the stabilization of emulsions, in the manufacture of herbicides, cosmetics, antihistamines, are also of practical interest. ${ }^{1}$ Here are the results on the study of the antimicrobial activity of a number of alkyl derivatives of MEA (Table1).

The antimicrobial properties of substances have been studied in vitro by serial dilution in a liquid nutrient medium. ${ }^{2}$ Staphylococous aurous strain N=209 "P", as the most stable species from the coccus group of bacteria, and Escherichia coli 0 III B:4-24, as the most stable species from enterobacteria, were used as indicator microorganisms. Test cultures by morphological, tinctorial, and cultural and biochemical properties are typical. Bacteria were cultured on MPA and MPB ( $\mathrm{pH}$ $=7.2-7.4$ ). In the experiments, second generations of daily agar test cultures were used.
The substances $\underline{\mathbf{2}}, \underline{\mathbf{3}}$ have activity in relation to the Staph aureus strain \#209. The substance $\underline{\mathbf{2}}$ surpasses the antimicrobial ethogenium (ethylene-1,2-bis/N-dimethylcarbodecoxymethylammonium dichloride) used in medical practice for anti-staphylococcal activity and can be used in the chemical and pharmaceutical industry to produce an anti-staphylococcal preparation. ${ }^{2}$ The studied compounds are not active against gram-negative microorganisms (Escherichia coli).

Acute toxicity of substance $\underline{\mathbf{3}}$ was studied in non-native white rats weighing $180-200 \mathrm{~g}$ when administered orally. The $\mathrm{LD}_{50}$ of substance $\underline{3}$ for white mice when administered orally is $145 \mathrm{mg} / \mathrm{kg}$.

The bactericidal properties of the substances were studied by disinfection of bathy test objects contaminated with a microbial suspension (containing $2 \mathrm{ml}$ microbial bodies in $1 \mathrm{ml}$ ), in reference strains of Escherichia coli (1257) and Staphylococcus aureus (906), in exposures 5, 10, 15, 20, 25, 30 minutes. Each concentration is tested in at least three replicates.

Table I Physical-chemical data of synthesized compounds

\begin{tabular}{|c|c|c|c|c|c|c|}
\hline № & Compound & B.p. $\mathrm{O} / \mathrm{mm}$ & $n_{\mathrm{D}}^{20}$ & $n_{\mathrm{D}}^{20}$ & IR & NMR \\
\hline 1 & $\mathrm{HOCH}_{2} \mathrm{CH}_{2}-\mathrm{N}_{1}^{-\mathrm{H}}-\mathrm{CH}_{2} \mathrm{CH}=\mathrm{CH}_{2}$ & $102-103 / 25$ & 14,637 & 0,8964 & $\begin{array}{l}1630,980,3020 \\
\left(\mathrm{CH}=\mathrm{CH}_{2}\right) \\
3200-3400(\mathrm{OH} \\
\mathrm{NH})\end{array}$ & $\begin{array}{l}2,65 \mathrm{~T}\left(2 \mathrm{H}, \mathrm{NCH}_{2} \mathrm{CH}_{2}\right) ; 3,18\left(2 \mathrm{H}, \mathrm{CH}_{2} \mathrm{C}=\mathrm{C}-\right) ; \\
3,5 \mathrm{c}(1 \mathrm{H}, \mathrm{OH}) ; 3,62 \mathrm{M}\left(2 \mathrm{H}, \mathrm{CH}_{2} \mathrm{CH} \underline{H}_{2} \mathrm{OH}\right) ; \\
4,95 \div 6,25\left(3 \mathrm{H}, \mathrm{C} \underline{\mathrm{H}}=\mathrm{C}_{2}\right) ;\end{array}$ \\
\hline 2 & ${ }_{2} \mathrm{HOCH}_{2} \mathrm{CH}_{2}-\mathrm{N}_{\mathrm{C}_{5} \mathrm{H}_{11}}<\mathrm{H}$ & $140-142 / 10$ & 14,465 & 0,8531 & - & $\begin{array}{l}0,85\left(3 \mathrm{H}, \mathrm{CH}_{3}\right) ; 1,28 \mathrm{м}\left(6 \mathrm{H},\left(\mathrm{CH}_{2}\right)_{3} \mathrm{CH}_{2}\right) \\
2,56 \mathrm{M}\left(4 \mathrm{H}, 2 \mathrm{NC} \underline{H}_{2}\right) ; 3,12 \mathrm{c}(1 \mathrm{H}, \mathrm{OH}) ; 3,52 \mathrm{M} \\
\left(2 \mathrm{H}, \mathrm{CH}_{2} \mathrm{O}\right)\end{array}$ \\
\hline 3 & ${ }_{3}^{\mathrm{HOCH}_{2} \mathrm{CH}_{2}-\mathrm{N}} \underset{\mathrm{C}_{9} \mathrm{H}_{19}}{-\mathrm{H}}$ & $202-203 / 5$ & 14,599 & 0,8687 & - & $\begin{array}{l}0,82 \mathrm{c}\left(3 \mathrm{H}, \mathrm{CH}_{3}\right) ; 1,22 \mathrm{c}\left(14 \mathrm{H},\left(\mathrm{CH}_{2}\right)_{7}\right) ; 2,41 \mathrm{M} \\
\left(4 \mathrm{H}, 2 \mathrm{NC} \underline{H}_{2}\right) ; 3,33 \mathrm{M}\left(2 \mathrm{H}, \mathrm{CH}_{2} \mathrm{O}\right) ;\end{array}$ \\
\hline
\end{tabular}

\section{Conclusion}

From the obtained data (Table 2) it is visible that Nonylethanolamine (3) exhibits very high bactericidal activity. Simplicity of synthesis of this compound predetermines its application in practice as antimicrobial derivative.

\section{Acknowledgements}

None.

\section{Conflict of interest}

Author declares that there is no conflict of interest. 
Table 2 The antimicrobial activity of synthesized amine $(\mu \mathrm{g} / \mathrm{ml})$

\begin{tabular}{lllll}
\hline \multirow{2}{*}{ Substance } & \multicolumn{2}{l}{ Test culture } \\
\cline { 2 - 5 } & \multicolumn{2}{l}{ Staph aureus } & \multicolumn{2}{l}{ E. coli 0 III B:4 } \\
\cline { 2 - 5 } & MBSC* $^{* * *}$ & MBC** & MBSC & MBC \\
\hline 1 & $\mathrm{X}^{* * *}$ & $\mathrm{X}$ & $\mathrm{X}$ & $\mathrm{X}$ \\
2 & 3,9 & 7,8 & $\mathrm{X}$ & $\mathrm{X}$ \\
3 & 0,03 & 0,12 & $\mathrm{X}$ & $\mathrm{X}$ \\
\hline
\end{tabular}

Abbreviations: MBSC, minimal bacteriostatic concentration; MBC, minimal bactericidal concentration; $X$, absence of activity in the initial absence of activity in the initial

\section{References}

1. GH Torosyan. The Selective N-Alkylation of Monoethanolamine in PTC Condition. MOJ Bioorganic \& Organic Chemistry. 2018;2(1):19-21.

2. AS Labinskaya. The Microbiology, Microbiological research technique. Medicina (Russia) M. 1978; p. 394 